\title{
Arguments to Apply Constitutional Guarantees in the Private Sector
}

\author{
Md. Toriqul Islam* \\ University of Malaya, Malaysia
}

\begin{abstract}
Constitutional guarantees are such a body of interests or basic human rights which are inevitable for each human being. These rights are principally inherent, inalienable, and universal, and therefore, irrespective of race, sex, caste, color, or religion, everyone can enjoy them. Constitutional guarantees are distinct from all other rights and privileges because of at least two unique characteristics, such as intrinsic in nature, and inalienability. These guarantees are crucial in the state-individual relations, and recognized by major laws of the civilized nations, and often enshrined in the national constitutions. For instance, the US Constitution signifies the essence of these rights through the expression of life, liberty, and the pursuit of happiness. Nonetheless, very often, many citizens across the globe are deprived of these rights on numerous pretends and grounds, and mostly, on the public-private dichotomy. This study examined contemporary legal and philosophical discourses as to whether the constitutional guarantees of human rights apply in the private sectors in Malaysia, India, and the United States. This study used doctrinal legal research methodology with a qualitative approach based on library resources. The findings of this study showed that constitutional guarantees, primarily human rights, are presumed to have been neither created nor made but originated like organic growth. Accordingly, no authority can take them away. By examining various logics from theological to socio-historical points of view and the theory of international law, this study concluded that constitutional guarantees, particularly the equal protection of the law, should apply horizontally to cover both public and private sectors.
\end{abstract}

KEYWORDS: Constitutional Guarantees, Human Rights, Public-Private Sectors.

Copyright @ 2021 by Author(s)

This work is licensed under a Creative Commons Attribution-ShareAlike 4.0 International License. All writings published in this journal are personal views of the authors and do not represent the views of this journal and the author's affiliated institutions.

HOW TO CITE:

Islam, Md. Toriqul, "Arguments to Apply Constitutional Guarantees in the Private Sector" (2021) 8:2 Lentera Hukum 175-210. DOI: <https://doi.org/ 10.19184/ejlh.v8i2.24232>.

Submitted: 07/04/2021 Reviewed: 09/04/2021 Revised: 02/07/2021 Accepted: 07/07/2021

\footnotetext{
*Corresponding author's e-mail: toriqul@siswa.um.edu.my
} 


\section{INTRODUCTION}

Constitutional guarantees become important aspects amidst the more increasingly discourse on human rights protection. Over the years, various governments and non-government actors worldwide frequently deprive individuals of their constitutional safeguards in the name of stability, discipline, emergency, security, or war. ${ }^{1}$ Being one of the marginalized or backward sects, some ethnic groups may favor others. Although constitutionally acknowledge the equal protection of the law for all casts, sects, and ethnic groups, some countries promote affirmative action favoring one ethnic group to the rest of the others. For example, Article 8(1) of the Federal Constitution of Malaysia affirms the guarantee of equality before the law and the equal protection of the law. Nonetheless, this constitution includes provisions for reserving quotas in public services, education, scholarship, and getting a business license for the native Malays (natives of either the Sabah or the Sarawak States), who are generally known as Bumiputera. The laws, policies, and politics encompassing Bumiputera favor the Malay Muslim Community. However, such policies manifestly outrage the constitutional provisions of the equal protection of the law and nondiscrimination among citizens.

Almost all constitutions acknowledge some basic human and fundamental rights as constitutional guarantees. For example, the Indonesian Constitution affirms numerous human and fundamental rights, such as equality before the law, the right to life, and the right to be free from

1 Citizens are often deprived of their constitutional guarantees, especially during war or emergency. This is recognized in almost every constitution of the civilized world. For example, the US Constitution approves the restriction on the constitutional guarantees by Articles 1 and 9, Clause 2. See William B Fisch, "Emergency in the Constitutional Law of the United States" (1990) 38:Suppl_1 Am J Comp Law 389-420 at 389-420. Similarly, the Constitution of Malaysia restricts constitutional guarantees on the same grounds as Articles 149 and 150. Ramdas Tikamdas, "National Security and Constitutional Rights" (2003) 32:1 J Malays Bar 18. Also, the Indonesian Constitution, in applying the emergency laws, restricts civil and political rights under national security. Jayus Jayus \& Muhammad Bahrul Ulum, "Presidential Power's Limitation to Emergency Provisions in Indonesia" (2020) 8:2 J Cita Huk 343-362 at 347. 
discriminative treatment. ${ }^{2}$ There shall have equal opportunities and guarantees of enjoyment of these human rights for all Indonesian citizens irrespective of race, sex, religion, color, caste, and ethnicity. Nevertheless, the reality goes too far from this logical expectation.

There are several cases in which the treatment of Indonesia to the minority sects raised serious questions. In particular, the persecution against the Ahmadiyah and Shia community, denial for establishing non-Muslim places of worship, imprisonment of former Jakarta's governor Basuki Tjahaja Purnama in the blasphemy case are few examples in which Indonesia's treatment toward minority sects gave rise to questions. ${ }^{3}$ However, there are cases in which large-scale infringement incidents occur but mostly remain unaddressed because of public and private considerations. It gives rise to some questions of vital importance, whether the constitutional guarantees apply to the public sectors only? Do the privileges of the constitution extend to citizen-government relationships only? Is it a jurisprudential error to hold the view that the constitutional guarantees of equality apply to everyone? Can a private business or corporation form a state within a state whose only law is the whim of the CEO? Can a country having a supreme constitution shut out its values to the private sectors only?

In the absence of explicit legislative provisions forbidding racial or religious discrimination in the private sector, can private businesses choose whom to do business with and create an apartheid type of business and commercial milieu? Can private hospitals, taxis, buses, and grocery shops have billboards inviting customers from a particular group, sect, or religion only? Can an emergency unit of a private hospital close its doors to people of ethnicity or religious ground? Can the Courts lean on the fundamental liberties of the constitution to review the legality of these divisive actions? Opinions are profoundly divided. ${ }^{4}$

2 Articles 27, 28A, 28B(2), 28H(1), and 28I(2) of the 1945 Constitution of the Republic of Indonesia.

3 Joeni Kurniawan, "When Human Rights are not Enough" (2018) 2:1 J Southeast Asian Hum Rights 236-247 at 236.

4 Shad Saleem Faruqi, "The Constitution and the Private Sector", Star Online, online: <https:/www.thestar.com.my/opinion/columnists/reflecting-on-the-law/2017/10/ 
Privatization enhances autonomy, even though the traditional foundational understanding between public-private bodies is not maintainable because of deregulation, excessive arbitrariness of their owners. ${ }^{5}$ Indeed, regardless of any definition, citizens must have these guarantees in every sphere of their lives. However, it is repenting that diverse bodies deprive people of these guarantees based on gender, color, caste, religion, public-private debate. This study aimed to analyze the contemporary debate on whether constitutional guarantees were applied in some countries' private sectors. They are Malaysia, India, and the United States. By a sharp analysis of a wide array of socio-historical, theological, and legal reasoning, this study argues, the constitutional guarantees, especially the equal protection of the law, cannot be taken away by any pretense. Instead, they should be implemented for all the citizens horizontally.

This study aimed to examine contemporary legal and philosophical discourses on whether the constitutional guarantees of human rights apply in the private sectors in Malaysia, India, and the United States. It has two main discussions. In the first place, this study examines the contemporary debates on whether the constitutional guarantees apply in the private sectors analyzing three leading cases from Malaysia, India, and the United States. Secondly, this study would search for the answer to that question based on the extensive literature covering the theological point of view, appeals of religions, principles of international law, and jurisprudential explanation. It deals with socio-historical arguments, normative ideology in receiving the constitution, reasonable expectations of law, the ideals of states constitutions and horizontal application of equality, and the obligatory international legal instruments. In conclusion, the paper offers a precise result on the question as to whether the constitutional guarantees apply everywhere.

26/the-constitution-and-the-private-sector-the-view-that-the-protection-of-theconstitution-is-restrict>.

5 Ramachandran, S \& Kessides, "Privatization and Deregulation: A Push Too Far?" in Econ Growth 1990 (World Bank, 1990). See also: The Impact of Decentralization and Privatization on Municipal Services: Report for Discussion at the Joint Meeting on the Impact of Decentralization and Privatization on Municipal Services, by Gabriele Ullrich, Hubertus Essenberg \& William Ratterree, Sectoral Activities Programme (Geneva: International Labour Organization, 2001). 


\section{METHODS}

This study adopted doctrinal legal research to achieve the research objectives by answering the research questions. It used a qualitative approach and was conducted based on library resources and the experiences of the researcher. To comprehend the relevant facts, findings, and issues, extensive literature was analyzed from primary and secondary sources, including international instruments, domestic laws, case laws, books, journal articles, and commentaries of famous scholars in the field. The study employed the content analysis technique in reaching the concluding remarks by way of the author's analysis. Finally, the findings have been demonstrated descriptively.

\section{DEBATES ON CONSTITUTIONAL GUARANTEES}

Constitutional guarantees or rights refer to a wide range of prerogatives, duties, powers, or even restraint of powers enshrined in the constitution. However, the trend of our time is to have a written constitution blessed with a handful of basic human rights therein and containing an express or implied declaration that all other laws will be justified in the condition of compliance with the provisions of the constitution. In association with the United States, Malaysia, and India, most nations have the written constitution figuring around 220 to date. ${ }^{6}$ It is noteworthy that five other countries do not have any written constitution in the strict sense, such as the UK, Israel, New Zealand, Saudi Arabia, and Canada. ${ }^{7}$ Again, in the Federal States, there is a practice of adopting state constitutions. For example, each state of the United States has own constitution.

In 1787, Alexander Hamilton ${ }^{8}$ surprisingly foresaw and warned that once the constitution will be undermined on the excuse of fear and war. ${ }^{9} \mathrm{He}$ further stressed that many pretenses might have destroyed the civil rights of

6 Tom Ginsburg \& James Melton, Innovation in Constitutional Rights (2012).

7 Gerhard Robbers, Encyclopedia of world constitutions (New York: Facts On File, 2007).

8 Alexander Hamilton (1780-1804) was an American statesman and one of the United States' founding fathers.

9 Ana Dhamo, "United States of America and Constitutional Guarantees" (2015) 6:3 Mediterr J Soc Sci. at 242. 
the United States. ${ }^{10}$ The prediction of Alexander Hamilton has been justified in letters after the terrorist attack on 11 September by the subsequent adoption of the Patriot Act, 2001. ${ }^{11}$ At times, women, especially pregnant women, were degraded differently in the workplace, in Malaysia, India, and the United States. ${ }^{12}$ Owners of the private enterprise often misbehave with their employees, and sometimes they are fired without any logical ground. One can scarcely term this as an illegal activity because of a manifest nineteenth-century common law principle, the contract at will. ${ }^{13}$ All these need to be redressed.

Private businessmen in some jurisdictions chose whom to do business with, ${ }^{14}$ and in some personal law cases, women got half of their family property than their counterparts. Most ridiculously, an adult girl cannot marry someone she chooses without her parents' permission. In some personal laws, women are neglected as a witness in some instances, like marriages. ${ }^{15}$ However, the underlying principles are well explained in a frequently cited Payne v. Western E Atlantic Railroad, $1884^{16}$ where the Court opined that a man is always free where, when, and what to purchase and sell; has the authority also to retain or dismiss his employees with proper logic, weak logic, or even no logic

10 Ibid.

11 Ibid at 243.

12 Natalie Kitroeff \& Jessica Silver-Greenberg, "Pregnancy Discrimination Is Rampant Inside America's Biggest Companies," NY Times, online: <https://www.nytimes.com/ interactive/2018/06/15/business/pregnancy-discrimination.html>.

13 Richard A Epstein, "In Defense of the Contract at Will" (1984) 51:947 Univ Chic Law Rev. at 947-982.

14 In 2017, two laundromats owners in Johor and Perlis, Malaysia, offered 'Muslim only' service, which ignited tremendous debates in the national and international arena. Subsequently, the owners of the launderettes were bound to abandon their nonsense idea due to the stern government action. Reacting over the issue, Sultan of Johor Sultan Ibrahim Ibni Almarhum Sultan Iskandar stated, 'this is not a Taliban state, and as the Head of Islam in Johor, I find this action to be totally unacceptable as this is extremist in nature.' See Sharanpal Singh Randhawa, "Muslim-only Launderette in Perlis", Star Online (29 September 2017), online: <https://www.thestar.com.my/news/ nation/2017/09/29/muslimonly-launderette-in-perlis-owner-who-does-not-wantcontroversy-urges-nonmuslims-to-go-elsewhere/>.

15 Kamrul Hossain, "In Search of Equality: Marriage related Laws for Muslim Women in Bangladesh" (2003) 5:1 J Int Women's Stud. at 96-113.

1681 Tenn. 507, 81 Tennessee 507. 
without having any guilty feeling. This practice is also allowed for the employee toward employer all through.

However, scholars are divided into two groups on whether constitutional guarantees apply to private sectors. In describing the UDHR as the 'Magna Carta' of the contemporary international human rights law, Richard Lillich observed certain rights such as the inherent dignity of human and equality contained in the constitution usually originated from the UDHR. They are inalienable rights for all human beings. ${ }^{17}$ Explaining the text of the Equal Protection Clause of the US Constitution, Jonathan F. Mitchell stresses that the doctrine of the Fourteenth Amendment does not allow any racial and other biased practices. The Fourteenth Amendment urges for equality and the equal treatment of law for everyone within a territory of a realm. ${ }^{18}$ Even equality is vital to materialize democracy by offering all people opportunities and participating in all democratic norms. ${ }^{19}$

In contrast, Graber and Teubner observed that constitutional guarantees do not apply directly in the private sphere as designed for state-citizens affairs. ${ }^{20}$ Of course, constitutional guarantees may sometimes apply indirectly in private sectors as integrity, social values, or morals of a right-minded man. In the US legal system, the standing view is that the constitutional guarantees, particularly the equal protection of the law, have a limited application because of the 'State action' conception.

The Fourteenth Amendment clause of the US Constitution only forbids the government authority from discriminating against non-government bodies. For instance, if a public educational institution bars a woman from taking a specific class without any cause or lawful ground, this would be deemed as prohibited State action. However, if the same happens in the private school, that would not be termed a violation of the Equal Protection Clause, even

17 Richard B Lillich, The Human Rights of Aliens in Contemporary International Law (Manchester University Press, 1984).

18 Jonathan F Mitchell, "Textualism and the Fourteenth Amendment" (2017) 69:5 Stanford Law Rev. at 1237.

19 Erlina \& Nika Normadilla, "Gender Analysis in Indonesia's Legislation Regarding Political Laws” (2020) 7:3 Lentera Hukum at 337-354.

20 Christoph B Graber \& Geunther Teubner, "Art and Money: Constitutional Rights in the Private Sphere?” (1998) 18:1 Oxf J Leg Stud. at 61-73 
though that is blatantly discriminatory. ${ }^{21}$ However, this study argues that constitutional guarantees, being treated as human rights in most cases, should be applicable everywhere. The preamble of the UDHR, for example, provides the basis of justice, liberty, and peace for the whole world lie in acknowledging the intrinsic worth of human personality, the equal and inalienable rights for all human beings. ${ }^{22}$ However, this is not practiced even in the established democracies. In Malaysia and many parts of the world, one can notice differences in the application of constitutional guarantees in public-private gender, caste, or religious grounds. ${ }^{23}$ Sometimes, there are adverse government treatments toward the citizens based on their employment status while applying constitutional guarantees. ${ }^{24}$ There are many unequal treatments in India, especially in personal laws concerning marriage, dowry, untouchability, sati, and unlawful restraint. All these are degrading and neglectful behavior to humanity and, simply, the gross violation of the basic human rights and constitutional guarantees at large. In all these cases, some basic human rights are violated in a broad sense. Such rights include, among others, equality, liberty, equal protection of the law, the freedom of religion, the right to education, the property right, and the right to work.

However, this should not be at all, as every human being is born equal in worth and rights; hence, everyone should be treated equally in all spheres of life. A careful examination of the prevailing legal systems of major nations reveals a frustrating account as to the application of constitutional guarantees in the private sector. To arrive at this conclusion, this study examines three leading cases. They are Beatrice Fernandez $v$ Sistem Penerbangan Malaysia $\varepsilon^{\circ}$ Anor, Air India v Nergesh Mirza, and Wal-Mart Stores Inc. v Dukes case of Malaysia, India, and the United States, respectively.

21 Lenora M Lapidus, Emily J Martin \& Namita Luthra, The Rights of Women: The Authoritative ACLU Guide to Women's Rights (New York: NYU Press, 2009) at 2.

${ }^{22}$ United Nations, Universal Declaration of Human Rights, 1948 (UDHR), General Assembly Resolution 217 A on 10 December 1948.

23 Abdul Malek Ahmad PCA, et al., "Beatrice Fernandez v Sistem Penerbangan Malaysia \& Anor" (2005) 3:681 Malay Law J.

24 Ibid. 


\section{A. Malaysia}

In Beatrice Fernandez v Sistem Penerbangan Malaysia E Anor case, ${ }^{25}$ the appellant Ms Beatrice Fernandez began working as a flight steward (with B grade salary scale) for Malaysian Airlines (MAS) from 1980. After serving 11 years at MAS, Ms Fernandez became pregnant, and subsequently, MAS authority terminated her job in 1991 based on a collective agreement ${ }^{26}$ (dated 3 May 1988). The collective agreement contains discriminatory provisions that allow the authority to fire a female flight attendant after becoming pregnant if she does not resign willingly. ${ }^{27}$

In November 1991, Ms Fernandez filed a petition to the High Court claiming the invalidity of numerous provisions of the collective agreement because of Article 8 of the Malaysian Constitution. Among others, Article 8 of the Malaysian Constitution guarantees the equal protection of the law and prohibits discrimination among citizens based on religion, race, descent, place of birth, and gender. She raised questions on the validity of her termination order, claiming to contravene section 14 (3) of the Industrial Relations Act 1967 and 7 of the Employment Act 1955.

Section 14 (3) of the Industrial Relations Act affirms if any term of employment of the collective agreement appears as less favorable or inconsistent with any provision of any written law applicable to the employees working under the said collective agreement, such provision will be deemed as void to the extent of such inconsistency. The favorable provisions of the law will be substituted in the case. A similar provision is contained in section 7 of the Employment Act 1955.

25 Ibid.

${ }^{26}$ A collective agreement (CA) is a written agreement made between an employer and a trade union acting on behalf of its members. In fact, under s.17 (2) IRA, a CA is an implied term of the contract between the worker and employer. Thus, the terms and conditions of the individual contract of employment cannot derogate from (not less than) the terms and conditions of the CA. See the discussion on the effects of a collective agreement in Venkatraman Anantaraman, Malaysian Industrial Relations: Law E Practice (Universiti Putra Malaysia Press, 1997) at 95-99.

27 The maternity policy of the Malaysian Airlines System (MAS) at the time and to date refers to resignation or dismissal upon a third pregnancy. Thus, maternity benefit is allowed for up to two children only. Abdul Malek Ahmad PCA, et al., supra note 23. 
Based on the above provisions of these two laws, Ms Fernandez claimed for the costs, compensations, and other interests, but her application was dismissed in 1996 and 2004 by the High Court and the Court of Appeal, respectively. It was held in the Court of Appeal that no remedy is available to Ms Fernandez as the constitutional guarantees are available to the citizens if the public authority infringes them. There is no proof for MAS to show as a public authority. Even if MAS is shown as a public authority nevertheless, the equal protection clause as laid down in Article 8(1) is not applicable in the case because the collective agreement cannot be deemed as the 'law' in the lawyer's sense. Article 8(2), which prohibited gender discrimination, cannot be applied with retrospective effect in the case as added in the constitution after an amendment in 2001.

In considering termination of service on pregnancy, the Court questioned the employability of the Employment Act to that case. The Federal Court neither considered Article 5 of the Malaysian Constitution nor the Employment Act 1955, which could ensure the right to work of the applicant during her pregnancy. ${ }^{28}$ Another critical issue was to consider whether the terms and conditions of the convention on the Elimination of All Forms of Discrimination Against Women, 1979 (CEDAW) can be applied against the collective agreement. However, it was not tested by the Federal Court. ${ }^{29}$ However, the Court gave a noteworthy observation as follows:

"It is not hard to realize that employing a pregnant air hostess in a flying aircraft is not wise, as it is tough to continue walking for hours in the aircraft during pregnancy. Considering the hardness, most probably, no airlines company shows any interest in employing a pregnant steward in the flying aircraft." ${ }^{30}$

It is noted that Malaysia has no anti-discrimination laws for the private sector. This affirms, in the literal interpretation, until the law changes, private businesses are free to adapt and apply the equality clause of the

28 Jashpal Kaur Bhatt, "Gender Discrimination in Employment- How far does Art 8 of the Federal Constitution Guarantee Gender Equality” (2006) 6 Malay Law J.

29 Bhatt, supra note 28 at 44-68.

30 Salbiah Ahmad, Gender Equality under Article 8: Human Rights, Islam and 'Feminisms' (Malaysia: The Malaysian Bar, 2005). 
constitution as their wishes. It could have been dissimilar if a law like the Private Higher Educational Institutions Act 1996 explicitly mandates that membership of a private higher educational institution should be open for all. ${ }^{31}$ Though after the 2001 amendment in Article 8(2) of the Malaysian Constitution, there are no discriminatory provisions in applying constitutional guarantees, it retains several reservations as well. ${ }^{32}$ Hence, the debate encompassing the public-private dichotomy has never been ended completely. Moreover, Article 8(5) explicitly discards applying the equality clause to the case of "personal law" and to the freedom of religion, too, as guaranteed in Article 11. Thus, a careful reading suggests that the Muslim 'personal law' shall remain untouched by Article $8 .{ }^{33}$

\section{B. India}

Whether the constitutional guarantee of equality applies to private sectors in India has been tested by the landmark decision of the Indian Supreme Court in Air India Vs Nergesh Mirza 1981 case. $^{34}$ In this case, the appellant questioned the terms of the service rules of the air hostess, which postulate that the service of an air hostess will come to an end by first pregnancy, or marriage, or 35 years of age, whichever happened first. ${ }^{35}$ In addition, the service rules contain some other discriminatory provisions. For instance, before passing four years in the service, an air hostess having 19 years old cannot marry. If she got married, breaking that rule, she would face termination on her first pregnancy. However, an air hostess could continue her job until she got 35 years; on the other hand, her male counterpart's retirement age is 58 years old. ${ }^{36}$ Thus, Ms Mirza filed the case against Air India International, a government-run agency on gender discrimination.

31 Faruqi, supra note 4.

32 See, Federal Constitution 1957, Malaysia, Article 8(5) (a-f).

33 Bhatt, supra note 28 at 10.

34 AIR (1829), SCR 1982 (1) 438.

35 Working Paper No.17: Gender Equality and Social Dialogue in India, by Kamala Sankaran \& Roopa Madhav (ILO, 2010) at 25.

36 The Financial Express, "A Gender Bending Judgement," Financ Express, online: $<$ https://www.financialexpress.com/archive/a-gender-bending-judgement/88692>. 
The Supreme Court of India observed that the service as an air hostess is a distinctive job from the AFPs (Air Flight Pursers) in many terms, such as the service rules, promotions, and grades. ${ }^{37}$ The Court also opined that maintaining different service rules for an air hostess is in no way a discriminatory system. That does not infringe on Article 16 (1) of the Indian Constitution. The Court also could not see any dictatorial condition when a cabin crew lost their job because of marrying within four years of service. The Court overruled regulation 46 of the service regulations to the effect that an end of a job on first pregnancy is invalid. Moreover, the Court reversed another regulation that provided the Managing Director with an unfettered authority in extending the tenure of the job of a cabin crew from 35 years to 45 years of age on the condition of physical fitness.

The Supreme Court of India adopted the decision following the decision of Northern India Caterers $v$ State of Punjab $1967 .{ }^{38}$ A Punjab law ${ }^{39}$ rendered a brief procedure granting two options by the collector to oust an unauthorized occupant from the public premises. For instance, to evict under the special law or to file an ordinary suit for eviction. This provision of Panjab law was challenged and subsequently declared void, considering that it allows unchecked discretion in the collector, which was likely to be abused. ${ }^{40}$

Countrywide agitation continued by the cabin crews on the retirement issue, and some new cases were also initiated in the courts. The Indian Supreme Court applied the decision of Nergeesh Meerza case in Air India Cabin Crew Association v Yeshaswinee Merchant $2003^{41}$ neglecting the constitutional guarantee of non-discrimination. The Court justified its decision holding on a term of the collective agreement that postulated retirement age as a cabin crew shall extend to the age of 50 . The Court observed that to go for retirement before 58 like the male cabin crew is not a discriminatory provision. An air hostess enters into her service being consented to that term

\footnotetext{
37 Sankaran \& Madhav, supra note 35.

38 AIR SC 1581.

39 Punjab Public Premises and Land (Eviction and Rent Recovery) Act, 1959, Act 31 (India).

40 Ibid.

41 III LLJ 1 (SC); [2004] AIR SC 187.
} 
of the collective agreement. ${ }^{42}$ Later, the Petition Committee of the Lok Sabha (House of the People, Indian Parliament) was involved with the issue and supported the view of the Court, i.e., there can be varying ages of retirement on gender. Finally, the federal government directed Air India in October 1989 not to differentiate in the retirement age on gender and allow both males and females to continue their service until 58 years. ${ }^{43}$

With this direction from the central government, Air India revised the retirement age allowing identical tenure for both male and female cabin crews. It also decided to designate the executive female cabin crew as inflight supervisors on competency. However, Air India Cabin Crew Association, Air India Air Hostesses Association, and the male cabin crews simultaneously challenged the decision of Air India. In its decision, the Delhi High Court opined in 2007 that granting female executive cabin crew to act as in-flight supervisors was to eradicate discrimination against women and not impose inequality on male cabin crew. The Delhi High Court also observed that by allowing female cabin crews as in-flight supervisors, Air India had broken the 'glass ceiling. 'There is no problem with it from the constitutional point of view. ${ }^{44}$

However, this study argues that in the broader perspective, the equality clause implies that the treatment of law shall be identical for all in every sphere irrespective of race, sex, color, religion, birthplace, property, social, or political status. ${ }^{45}$ Adopting this liberal construction, Article 14 outlines the Republic of India shall ensure equality and the equal treatment of law for every individual within its boundary. ${ }^{46}$ In addition, the preamble of the Indian Constitution explicitly pledges also to ensure justice, freedom, equality, and enhance brotherhood. ${ }^{47}$ In the words of G. S. Ghurye-Justice, it covers all economic, social, and political issues. Again, equality means and includes many more. For example, equal opportunity in property, even in

42 The Financial Express, supra note 36.

43 Sankaran \& Madhav, supra note 35 at 26.

${ }^{44}$ Rajendra Grover v Air India Ltd. $\mathcal{E}^{\circ}$ Anr, 2007, SLP(C) Nos. 20773-20778.

45 I Jennings, The Law and the Constitution (London: University of London Press, 1963) at 49.

${ }^{46}$ Chiranjit Lal Chawdhary v Union of India, 1951 AIR SC 51.

47 Preamble, Constitution of India, 1950. 
status. Both equality and justice aim to strike the roots of the caste system too. The people of India avow for implementing equality and eliminating the unequal treatment in economic and social affairs. ${ }^{48}$

The literal interpretation of the Indian Constitution places the obligations upon the government and its agencies, not on private parties on the questions of constitutional human rights. ${ }^{49}$ Nonetheless, the essence of Articles 14, 15 , and 16 signify that there is no scope of discrimination among the citizens on the ground of race, sex, caste, religion, and birthplace. In addition, Article 15(1) imposes a negative obligation on the state, whereas Article 15(2) imposes a positive obligation on private parties. ${ }^{50}$ Accordingly, one private party can sue another private party too for breaching the constitutional guarantees. ${ }^{51}$

Again, the Indian Constitution prohibits untouchability practices in Article 17 and abolishes using different titles in Article 18, nursing its promise toward equality. ${ }^{52}$ Furthermore, other than the provisions enumerated in the fundamental rights, the Indian Constitution promotes the high ideal of equality. For example, Article 38 states that India shall endeavor to reduce the disparities in earnings and remove imbalances in rank, conveniences, and possibilities among general and their groups. ${ }^{53}$

Article 46 pledges to nurse the economic and academic interests of the weaker sections, tribal castes, scheduled castes and save them from all kinds of victimization and social inequality. ${ }^{54}$ However, Article 340 promises to nurse the same ideals, providing that the President can appoint an individual designated as a commissioner to look into the cases of the weaker sections of

48 G S Ghurye, Caste and Race in India (Popular Prakashan, 1969) at 409.

49 Aharon Barak, "Constitutional Human Rights and Private Law" (1996) 3:2 Rev Const Stud. at 218.

${ }^{50}$ Krishna Chandra Dwivedi, Right to Equality and the Supreme Court (Deep \& Deep Publications, 1990) at 77.

51 Laurence H Tribe, American Constitutional Law, 2d ed (Foundation Press, 1978) at 1688. See also Amar et al., "Child Abuse as Slavery: A Thirteenth Amendment Response to DeShaney" (1992) 105:6 Harv Law Rev. at 1359.

52 Constitution of India, supra note 47, Articles 17-18.

53 Ibid, Article 38 (2) (emphasis added).

54 Ibid, Article 46. 
the community, ${ }^{55}$ whereas Article 335 affirms for ensuring positions of the scheduled castes and tribes in the public employment. ${ }^{56}$

\section{The United States}

In Wal-Mart Stores, Inc. v. Dukes, ${ }^{57}$ a class of women workers filed this case against the Wal-Mart stores in the allegation that the Wal-Mart authority discriminated against the female employees, as they paid women less, promoted fewer in the administrative positions, and delayed in the promotion process of the female employees. In the course of proceedings, the case came to the US Supreme Court as a class action, and later, the oral arguments took place on 29 March 2011. ${ }^{58}$ A lower-level female employee named Betty Dukes (P), with another five of her fellow female workers of Walmart, filed the case against the company as a class action on the ground of infringement of their civil rights.

The plaintiffs fulfilled the legal stipulations as laid down in Rule 23(a)(2) and 23(b)(2). ${ }^{59}$ Accordingly, the Northern District Court of California certified their case as a class action. They were a group of more than 1.5 million members working in the Wal-Mart from 26 December 1998. WalMart (D) appealed to the Court for requiring a single case from each employee because of the difficulties in handling a class action of more than 1.5 million employees and high costs. The US Court of Appeals (Ninth Circuit) affirmed the class action like the District Court but searched for the answers to the following questions. First, whether there can be a class of more than one million female employees under the management of only one company throughout the United States. Second, whether the class certification is justified where there is no commonness of fact, especially in

55 Ibid, Article 340.

56 Ibid, Article 335.

57 Wal-Mart Stores, Inc. v Dukes, 2011, 131 S. Ct. 2541, 564 US 338, 180 L. Ed. $2 d 374$.

58 National Women's Law Center, "Supreme Court Decision in Wal-Mart v. Dukes," Natl Womens Law Cent, online: <https://nwlc.org/resources/supreme-court-decisionwal-mart-v-dukes/>.

59 Rule 23 of Federal Rules of Civil Procedure prescribes provisions for 'Class Actions.' It reads, one or more members of a class may sue or be sued as representative parties on behalf of all members subject to the fulfillment of certain conditions. 
terms of identical discriminatory service rules as required by the Federal Rules 23(a) and 23(2). Third, whether the monetary compensation is proceeded by the Federal Rules of Civil Procedure 23(b)(2) and (iv) if it is allowed, can a declaratory suit or injunction be initiated for the issue?

The US Supreme Court reversed the judgment of the first instances on 20 June 2011, which justified a class certification against Wal-Mart, and remarked that the claimants were unsuccessful in proving that all persons of the group held a common interest in the issue. The US Supreme Court contended that this case was shown as a class action on behalf of more than 1.5 million of the present and ex-female employees. However, it was filled by a few numbers of current employees; hence they are not representing the whole body of employees, and therefore, it is not a class action in the real sense. Therefore, the US Supreme Court suggested that anyone can file a suit on discrimination for her cause but not for others.

However, Justice Ruth Bader Ginsburg, who dissented the US Supreme Court's decision opined, is unfortunate that the appellant female employees could not prove their claims. There were numerous allegations against WalMart, and adequate evidence that $70 \%$ of employees were women, but they held $33 \%$ of the management positions. Therefore, she remarked that the Supreme Court disqualified the class action at the beginning point. ${ }^{60}$

Justice Antonin Scalia believed that the plaintiffs were supposed to demonstrate that Wal-Mart adopted a common strategy of discriminating against women employees. However, they had altogether failed to establish the truth. ${ }^{61}$ It is entirely doubtful that a corporate giant like Wal-Mart was running by the fanciful discretion of its managers without having some common directions. ${ }^{62}$ Like Justice Ruth Bader Ginsburg, he further

60 Robert Barnes, "Supreme Court Blocks Massive Sex-Discrimination Suit against Wal-Mart," Wash Post, online: <https://www.washingtonpost.com/politics/supremecourt-blocks-massive-sex-discrimination-suit-against-walmart/2011/06/20/AGCQ81cH_story.html>.

${ }^{61}$ Bill Mears, "Supreme Court Rules for Wal-Mart in Massive Job Discrimination Lawsuit," CNN, online: <http://edition.cnn.com/2011/US/06/20/scotus.wal.mart. discrimination/index.html>.

62 Steven Greenhouse, "A New Hurdle for Suits Brought on Behalf of Many," NY Times, online: <http://www.nytimes.com/2011/06/21/business/21class.html>. 
remarked that the plaintiffs could not establish that the service rules of WalMart were discriminatory for female employees. ${ }^{63}$ Finally, Justice Scalia observed, it is insupportable to let a class action proceeded on service discrimination where monetary compensations are assessed on a liberal prescription for each claimant without estimating the costs of how much they had to suffer each.

Justice Harlan, in another case, opined, in the exercise of civil rights, the US Constitution is color and caste-blind. Thus, the constitution shall never allow any public body to discriminate among the subjects while enjoying these privileges. ${ }^{64}$ However, the US Supreme Court held that even though the Fourteenth Amendment to the constitution was not to discriminate among the people, this aims to block discrimination between black and white, not extended to sex discrimination. ${ }^{65}$

Historically, the long-nursed national traditions, beliefs, and prevailing religions have played essential roles in shaping the variant viewpoints regarding equality in Malaysia, India, and the United States. India's rich but complicated social hierarchy tradition has been reflected in the people's views regarding equality. To the Indians, equality is rather a collective concept, and the notion of ideal equality aims to abolish the caste systems and the inferiority complexities. ${ }^{66}$ On the other hand, the Americans focused historically on the equality of individuals, which may call the equality of opportunity or anti-discrimination principle. ${ }^{67}$ Whereas Malaysia stresses much on the public-private dichotomy in applying constitutional guarantees to the private sectors. ${ }^{68}$

63 Barnes, supra note 60.

64 Plessy v Ferguson, 1896, 163 US 537, 16 S. Ct. 1138, 41 L. Ed. 256.

65 Strauder v West Virginia, 1880, 100 US 303, 25 L. Ed. 664, 25 L. Ed. 2d 664, 310.

66 Nicole Lillibridge, "The Promise of Equality: A Comparative Analysis of the Constitutional Guarantees of Equality in India and the United States" (2004) 13 William Mary Bill Rights J. at 1301-1302.

67 John Hasnas, "Equal Opportunity, Affirmative Action, and the Anti-Discrimination Principle: The Philosophical Basis for the Legal Prohibition of Discrimination" (2002) 71 Fordham Law Rev. at 423.

${ }^{68}$ Federal Constitution of Malaysia, 1957, Articles 8 (2) and (4). 


\section{RATIONALE FOR APPLYING CONSTITUTIONAL GUARANTEES IN THE PRIVATE SECTORS}

\section{A. Theological Point of Views}

One cannot ignore the truth that equality is equity. For instance, if someone wants to secure justice and peace everywhere, she/he must ensure equality first. It is the teaching of major religions vis-à-vis international and regional legal instruments as well. Frankly speaking, human civilization has not been created in a day or based on one philosophy. Instead, it has taken long days to mature and based on many things, e.g., religion, morals, science, and law. Our understanding of major legal conceptions. They are right, duty, and equality, have had deep roots in religion. To be more specific, our perception of equality in modern days stands on religion; accordingly, the conception of equality should be interpreted in line with the teachings of religion.

Jeremy Waldron stresses that inability to extract the moral and political contents from the context thereof fails to make any sense of the idea that 'everyone is by nature equal. ${ }^{169} \mathrm{He}$ said not to think to mold and protect the idea of essential humanistic equality devoid of several religious solid bases. ${ }^{70}$ From ancient to modern days, many scholars, such as Aristotle, John Locke, Bernard Williams, John Rawls, Ronald Dworkin, and Amartya Sen, acknowledge the religious roots of certain legal conceptions, including constitutional guarantees. Aristotle, for example, in his famous passage, said-

"The foundation of a democratic State lies in several ideals, e.g., liberty, freedom, and equality. In a democratic State, everyone must have liberty, freedom, and equality in all spheres. Thus, in a free society, the poorer are powerful than wealthy people because of the huge size of the population. This is one of such principles that all democrats wish to nurse in the republic." 71

69 D Thomas, God, Locke, and Equality: Christian Foundations of John Locke's Political Thought (Cambridge University Press, 2001) at 13-14.

70 Ibid at 16.

71 Francis William Coker, Readings in Political Philosophy (Macmillan, 1914). 


\section{B. Appeal of Religions}

According to radiometric dating and other sources of evidence, it is believed scientifically that the Earth formed over 4 billion years ago. ${ }^{72}$ Genetic researches exhibit that the homo sapiens deviated from other vertebrates approximately 85 million years earlier. ${ }^{73}$ However, the human civilizations appeared first in Lower Mesopotamia (3000 BCE), which was succeeded by Egyptian civilization on the bank of the Nile River (3000 BCE). ${ }^{74}$ The city of Uruk was considered the oldest globally, which was established in c. 4500 BCE.$^{75}$ It is witnessed that in the early days of human civilization, men were highly impressed by religious precepts, ethics, and custom.

Subsequently, the formal State system was evolved, encompassing all affairs of the individuals and other social units within its grips. Later, the international and regional organizations started establishing having enormous promises, e.g., human rights, fundamental rights, civil rights, and constitutional guarantees. Thus, it is not surprising that our conceptions regarding current laws, rights, duties, constitution, and constitutional guarantees are greatly influenced by religious verses and sermons. Therefore, it is no exaggeration to say that the knowledge of equality has been generated first in the religion and subsequently transmitted into the international, regional, and national legal instruments. There are hundreds of religious verses regarding equality. ${ }^{76}$

72 G Brent Dalrymple, The age of the Earth (Stanford University Press, 1994) at 205-221.

73 Tyson, Peter, Meet Your Ancestors, NOVA ScienceNOW. PBS (2008).

74 Adam Hart-Davis, History: From the Dawn of Civilization to the Present Day (Penguin, 2012).

75 George P Fletcher, "In God's Image: The Religious Imperative of Equality Under Law" 1999 Columbia Law Rev 23. Joshua J Mark, "The Ancient City," online: World Hist Encycl <https://www.worldhistory.org/city/>.

76 Indeed, O mankind, We have created you from a single pair of men and women and classified you into different nations and tribes so that you can identify each other. Certainly, the most honored of you in Allah's view is the most just of you. Surah AlHujurat (49:13), the Holy Quran. Addressing Mankind, Prophet Muhammed (sm.) stated, your Almighty God is One, and so is your father. All of you have sprung from Adam, and The soil made him. He, who is usually upstanding, is the most regarded among you in the view of Almighty. No Arab is better than a non-Arab, no minority individual to a white one, or a white individual to a minority aside from loyalty. Tirmidhī, Muḥammad ibn 'İsá, -892, Jami Al-Tirmidhi. Maa Sharḥibi Tuhfat Al- 


\section{Principles of International Law}

No discrimination among people based on race, sex, religion, color, caste, and birthplace is the common slogan of major international legal instruments and theories. All are equal before the law is the only key to success in attaining world peace, solidarity, and cooperation. Thus, almost all major international legal instruments pledge to ensure equality in every sphere. In most cases, national legislation follows the enshrined principles of international legal instruments as the guiding principles. Hence, the philosophy of international law encompassing equality should be the philosophy of national legislation.

\section{Universal Declaration of Human Rights}

Among others, the first international instrument having provisions for the respect and promise of equality is the Universal Declaration of Human Rights, 1948 (UDHR). The UDHR suggests the member states nurse a feeling of brotherhood, as by born, every human being is free and equal in dignity, rights, reason, and conscience. ${ }^{77}$

\section{United Nations Charter}

The Charter of the United Nations is the following international instrument having the promise of respecting equal rights for all persons in the world. Referring to as one of the purposes of the United Nations, the Charter renders that reaffirms belief in basic human rights, in the honor and value of the person, in the equal opportunities for both male and female and of nations large and small. ${ }^{78}$

Ahwadhi / Li-Abd Al-Rahman Al-Mubarakfuri. Beirut (Lebanon): Dar al-Kitab alArabi (1970). In the view of Lord Jesus Christ, 'there is no Greek or Jew, sovereign or servant, man or woman, rather you all are equal. Genuinely and truly, I affirm you, neither a master is significantly distinguished from his slave, nor is he greater than who sent him. John 13:16, Galatians 3:28, New International Version (NIV), the Holy Bible.

77 UDHR, supra note 21, Article 1.

78 United Nations, United Nations Charter, 1945 (UN Charter), Article 1. 


\section{International Covenant on Civil and Political Rights}

In Part II of the International Covenant on Civil and Political Rights, 1966 (ICCPR), there remains a similar promise for respecting the equal protection of the law. For example, Article 2(1) of the ICCPR renders that every Member State to the existing Covenant shall, without any distinction whatsoever concerning their color, race, sex, religion, language, political or other beliefs, social or national origin, birth, property or another status, respect and guarantee for each individual in its boundary and under its authority the rights approved in the prevailing convention. ${ }^{79}$

\section{International Covenant on Economic, Social, and Cultural Rights}

The International Covenant on Economic, Social, and Cultural Rights, 1966 (ICESCR) urges the Member Nations to ensure all rights are enumerated without discrimination. For instance, Article 2(2) of the ICESCR requires the member states to guarantee that everyone shall enjoy the rights enumerated therein regardless of their sex, race, color, language, religion, national or social origin, wealth, birth, different status, political or other opinions. ${ }^{80}$ Besides, equal opportunity for all to be encouraged to work at a suitable higher level, and no considerations will be entertained other than seniority and competence. ${ }^{81}$

\section{International Convention on the Elimination of All Forms of Racial Discrimination}

Among the UN instruments, this particular convention contains detailed provisions against all sorts of racial discrimination among human beings. To eliminate discrimination and promote equal protection of the law, this convention asserts that the states parties restrain and eliminate all kinds of

79 United Nations, International Covenant on Civil and Political Rights, 1966 (ICCPR), General Assembly Resolution 2200A (XXI) on 16 December 1966, Article 2(1).

${ }^{80}$ United Nations, International Covenant on Economic, Social and Cultural Rights, 1966 (ICESCR), General Assembly Resolution 2200A (XXI) on 16 December 1966, Article 2(2).

${ }^{81}$ Ibid, Article 7(c). 
racial discrimination. It grants rights to everyone, regardless of race, color, or ethnic or national origin. Also, it ensures equal treatment of law, especially for the enjoyment of some crucial rights. They consist of access to justice, bodily integrity, civil and political rights, economic, social, and cultural rights, and access to recreational places. ${ }^{82}$

The present study contends that the norm 'equality' is firmly rooted in an aggregate sense of human dignity with some other diverse approaches. Discarding the prevailing formula of justifying equality by cutting humanity to a veritable point speaks about spiritual dictations to respect people equally. With this idealistic view, this study argues with the same tone as Fletcher that the prevailing approaches of evaluating equality by the stern State action and discrimination are faulty in both the theological and legal discourses. Hence, it needs to be revised. ${ }^{83}$

\section{Jurisprudential Explanation}

The bygone political ideology that constitutions are drafted to protect citizens only against the tyranny of the state is outdated thought in the modern progressive world. The reality today is that corporate power rivals and, in some instances, exceeds government power. Tyranny is tyranny, no matter what its source-public or private, offshore or onshore. It was an error of jurisprudence for the judges in the Beatrice Fernandez case of Malaysia to hold that the constitutional guarantees apply only against public authorities. However, many provisions of the chapter on fundamental liberties imply otherwise. For example, Article 8(1) of the Malaysian Constitution states that everyone is equal in the eye of law and shall be treated equally by the law. Again, Article 8(2) prevents discrimination in many areas, such as race, religion, descent, place of birth, and gender. However, other prohibitions can cover the private sectors too, such as applying any law as to acquiring, retaining, or settling of the asset; or running any business, occupation, or

82 United Nations, International Convention on the Elimination of All Forms of Racial Discrimination, 1965, General Assembly Resolution 2106 (XX) on 21 December 1965, Article 5 (e) (vi) \& (f).

${ }^{83}$ George P Fletcher, supra note 75 at 1608. 
service. ${ }^{84}$ Therefore, time requires broadening our horizons by abandoning the belief that constitutional guarantees apply against the state only. A person can be allowed to discriminate in the choice of his cook, driver, or maid if it comes to supplying a public service, where there is a public law element, the safeguards of constitutional and administrative law must apply. Not the issue of public law or private law, but the criterion of reasonableness should be employed, which was applied in Meor Atiqulrahman Ishak (2000) case, ${ }^{85}$ holding that a school can prevent the wearing of serbans at school assemblies. In Halimatussaadiah v Public Services Commission, ${ }^{86}$ it was held that the government as an employer could impose a reasonable dress requirement on its employee, barring women from wearing purdah to office despite the claim of freedom of religion.

\section{E. Socio-Historical Arguments}

Constitutional rights are such rights that can be enjoyed by all individuals against any intrusive power of the state indiscriminately. ${ }^{87}$ However, the application of this liberal approach is barred in the private spheres. It narrows the technical view of the exercise of powers among the trio: the individualpower-state. Today, the constitutional right of equality is interpreted in a strict formula because of several things, e.g., the unholy alliance between the rigid political theory and public law; less connectivity between state and society; public-private dichotomy, radical transformations in social life; the contractual theories, and so on. ${ }^{88}$ In applying constitutional rights in the private spheres, the public-private consideration does not make any sense, and hence, it is inevitably dysfunctional. It usually disregards the noble view

84 Federal Constitution of Malaysia, supra note 68, Article 8 (2).

${ }_{85}$ Meor Atiqulrahman bin Ishakv Fatimah bte Sibi, 2000, M.L.J.5 375.

${ }^{86}$ Halimatussaadiah v Public Service Commission, Malaysia E Anor, 1992 M.L.J.1 513.

87 Graber \& Teubner, supra note 20 at 61-73.

88 Andrew Clapham, Human Rights in the Private Sphere (Oxford: Clarendon Press, 1993). 
of 'Dicey' on fundamental rights that treat both the public and private spheres as the same actors and always require a horizontal effect. ${ }^{89}$

This study argues for the fundamental reconstruction of constitutional rights, as Clapham summarized. First, constitutional guarantees aim not only to preserve the rights of the individuals but also include some other nonindividual expressions of freedom in society. Second, constitutional liberties are aimed not only against the state's power but also the invasions of widespread social practices. Third, constitutional freedoms handle the issues of power and control any means of communication that can interfere with the other quarters of social life. ${ }^{90}$

Again, the sociological study of law profoundly examines the reasons for the emergence of constitutional rights in modern society. It reveals that in premodern layered societies, the protection of constitutional claims for the individual was unimaginable. ${ }^{91}$ The individual was completely inseparable from the social bonding; the legal claim was just 'status' not the 'right.' All rights began establishing, followed by the setting up of the individual entity among the social spheres. ${ }^{92}$ Thus, understanding constitutional guarantees from a sociological point of view clarifies that the individualistic explanation of constitutional claims is unnecessarily narrow. Thus, it should be replaced by institutionalized interpretation. ${ }^{93}$ The mere split between the state and society cannot cover all aspects of social affairs or the autonomy to be

89 Carol Harlow, “Public' and 'Private' Law: Definition without Distinction” (1980) 43:3 Mod Law Rev. at 241-265; P Cane, Public Law and Private Law: A Study of the Analysis and Use of a Legal Concept: Oxford Essays in Jurisprudence, 3 (Oxford: Clarendon Press, 1987) at 57.

90 Clapham, supra note 90 at 3.

91 L Bo Kaspersen, “Anthony Giddens: The Consequences of Modernity” (1991) 23:1 Politica at 112-114.

92 Niklas Luhmann, The Differentiation of Society (Columbia University Press, 1982) at 69-89.

93 A similar view is proposed by Joseph Raz, The Morality of Freedom (Clarendon Press, 1986). p. 253-254. Constitutional rights protect individual interests and collective goods, like the freedom of the press, free political speech, and others. However, an institutional perspective would see individual basic rights as instruments for protecting collective goods and define social institutions themselves as the subject of constitutional rights and translate this into procedural requirements. See also Graber \& Teubner, supra note 20 at 3. 
established by the constitution. Indeed, the central goal of each liberty, freedom, right, or claim is for pursuing peace only, and that is not possible to maintain until those privileges are secured for all. ${ }^{94}$

\section{F. Normative Ideology in Receiving the Constitution}

The constitution is the name of the embodiment that contains the sum of peoples' aspirations, yearnings, and wishes. It is the last resort of the mass people against all disparity, discrimination, and tyranny. Thus, the logical interpretation of the normative standards of the constitution does not support the public-private dichotomy while applying constitutional guarantees to the citizens. In his 'I Have a Dream speech,' Martin Luther King observed that while writing the majestic terms of the Constitution and the Declaration of Independence, our ancestors of the republic were like to endorse a promissory note ensuring the participation of all Americans. ${ }^{95}$ King rightly linked these two documents. The US Constitution is composed and accepted against the background of the war for independence from Britain. In contrast, the Declaration explored the Americans' dreams for the nature of the state they solicited. The Declaration of Independence states as follows:

"It regards the manifest truth that every human is created equal, and the Almighty Creator provided them with certain inalienable rights: inter alia, life, liberty, and the pursuit of happiness. People from the government by their consent to secure those rights. However, if the government becomes injurious to these ends, the people have the right to abolish and establish a new government." ${ }^{\text {96 }}$

Thus, the Declaration indicates the noble thinking of the founding architectures toward some great values, e.g., life, liberty, equality, freedom, and opportunity. It also shows that the government will be formed by the

${ }^{94}$ Helmut Willke, Stand und Kritik der neueren Grundrechtstheorie: Schritte ze normativen Systemtheorie (Duncker und Humblot, 1975).

95 Goodwin Liu, Pamela S Karlan \& Christopher H Schroeder, Keeping Faith with the Constitution (Oxford University Press, 2010) at 7.

96 Declaration of Independence of the United States of America, 1776. 
wish of the people to implement the aspirations enshrined therein, and the government will be ousted if they do not fulfill the people's desires.

\section{G. Reasonable Expectations of Law}

Generally, the law means a body of rules of human actions, behavior, or conduct enacted and enforced by the state. The central object is to ensure rights and maintain peace suppressing the wrongs. In doing so, it is a logical expectation from the law that it would never be repugnant to the interest of any person in any pretense. Most of the legislation of the civilized nations conform to this general and logical expectation. For example, the Civil Rights Act of 1870 of the United States asserts that everyone (black) is entitled to have full and equal advantages from all laws in terms of personal security and property like the whites. ${ }^{97}$ Moreover, the equal protection clause does not limit its boundary to the federal legislation only, rather laws of different States as well, and sometimes, applies to aliens also. ${ }^{98}$ Section 16 of the Civil Rights Act of 1870 outlines as follows:

"Everyone living in the USA shall have an equal right in contracts; can sue and be sued; provide evidence and enjoy the complete and same advantage from all laws and actions in securing his body and wealth like the white Americans. In addition, everybody shall have the same penalty, injuries, fines, charges, licenses, and taxes of all types, notwithstanding anything contained contrary in any enactment, ordinance, rule, or custom. ${ }^{\prime 99}$

\section{H. The Ideals of States Constitutions}

Though the US Constitution does not extend the theory of sex-based nondiscrimination. However, it is enlarged by the state constitutions even to the private sectors. Many state constitutions include provisions admonishing equal protection refusals by the central government. In addition, some state

97 Civil Rights Act, 1870 (USA) ch. 114, § 16, 16 Stat. 140, 144 (codified as amended at 42 U.S.C. $§ 1981$ (a) (2015) (emphasis added).

98 Mitchell, supra note 18 at 1286.

99 Civil Rights Act, supra note 99. 
constitutions contain provisions limiting the power of the state to nondiscrimination and inflicting the positive duty to secure equality in all spheres. ${ }^{100}$ The Federal Constitution, however, does not provide a similar mandate. The Constitutions of Texas ${ }^{101}$ and Massachusetts declared that equal protection of the law would never be refused or curtailed based on race, sex, creed, color, or national identity. ${ }^{102}$ Likewise, section 17 of the 1970 Illinois Constitution embodies- persons belonging to any race, sex, creed, color, sex, and national ancestry shall be free from discrimination while renting something; getting a promotion from his employer; engaged in the sale or rental of assets. ${ }^{103}$ Similarly, the Constitution of Louisiana states, a law cannot tyrannically, fancifully, or illogically discriminate persons because of sex, birth, age, culture, the condition of health, or political beliefs or alliances. ${ }^{104}$ The Constitution of Montana declares- in the practice of the political or civil rights, no State, institution, corporation, firm, or person shall discriminate with any individual based on sex, race, culture, color, social status or origin, or religious, and political views. ${ }^{105}$

\section{Horizontal Application of Equality}

Whether the constitutional guarantee of equality applies to the private sphere is one of the pressing questions in the whole body of constitutional laws. Many nations, inter alia, Switzerland, Germany, Spain, Canada, the

${ }^{100}$ Helen Hershkoff, "Positive Rights and State Constitutions: The Limits of Federal Rationality Review" (1999) 112:6 Harv Law Rev. at 1131-1196.

${ }^{101}$ Constitution of the State of Texas, 1876 (USA), Article I, § 3a. This provision has been read to go beyond "both the United States and Texas due process and equal protection guarantees." In re McLean, 725 S.W.2d 696, 698 (Tex. 1987) (“[T]he ... Amendment elevates sex to a suspect classification").

102 Constitution of the Commonwealth of Massachusetts, 1870 (USA), Article I, § 2.

${ }^{103}$ Constitution of the State of Illinois, 1970 (USA), Articles I, § 2, and $§ 17$.

${ }^{104}$ Constitution of Louisiana, 1974 (USA), Articles 1, § 3. This provision has been read to go beyond the decisional law construing federal constitutional equal protection; see State v Granger, 2008, 982 So. 2d 779, 787-88. Where a Louisiana state constitutional provision has been outlined to "go beyond" the comparable federal provision, in some settings, it may still provide no "additional protections." State v Kennedy, 2007, 957 So. $2 \mathrm{~d}$ 757, 779 (addressing a "cruel, excessive, or unusual punishment" claim in a death penalty case involving aggravated rape of a minor).

${ }^{105}$ Constitution of the State of Montana, 1972 (USA), Article II, § 4. 
EU, the UK, South Africa, Ireland, have adopted the horizontal approach of application in place of the vertical one. In several cantons of Switzerland, the 'Drittwirkung der Grundrechte' (impact on third parties) model has been accepted to apply constitutional guarantees to the private sector. ${ }^{106}$ Germany has also taken the 'Drittwirkung' theory too. ${ }^{107}$ The set principle is that human rights enumerated in the basic law (Grundgesetz) apply between private-public relations under public law and private parties under private law. It appears that the government, as an extremist power, violates human rights, but the harm may happen by the private actors to the private parties as well. ${ }^{108}$ Therefore, constitutional rights should apply to private parties too. In Brooks v Canada Safeway Ltd, 1989, ${ }^{109}$ the Canadian Supreme Court held that pregnancy and motherhood are among the most crucial social needs; accordingly, it is very much inequitable to shift the responsibility to one side of the population. It was also held that to terminate a female employee from her position due to pregnancy is clear discrimination on gender. ${ }^{110}$ In another case, Mrs Dekker, a Dutchwoman and the most suitable candidate for job placement, could not get the job because of her pregnancy. Mrs Dekker filed a suit against her employee, and later the issue had laid before the European Court of Justice (ECJ) in 1990. ${ }^{111}$ Taking note of article 141 and the Equal Treatment Directive, the ECJ opined that bias in the prospects of service based on pregnancy is straightforward prejudice and the gross infringement to the said instrument. ${ }^{112}$

The Sex Discrimination Act 1975 of the UK states, it is unlawful to undervalue a woman by her employer because of her sex and marital status. The Pregnancy Discrimination Act 1978 postulates that women with pregnancy or feeble because of childbirth or health complexities will get the

\footnotetext{
${ }^{106}$ Barak, supra note 49 at 246.

${ }^{107}$ Eric Engle, “Third Party Effect of Fundamental Rights (Drittwirkung)" (2009) 5:2 Hanse Law Rev. at 165.

${ }^{108}$ Barak, supra note 49 at 243.

1091 SCR 1219.

${ }^{110}$ ZA Aziz, Developing the Doctrine of Equality-Sameness and Differences (Malaysia: The Malaysian Bar, 2005).

${ }^{111} \mathrm{C}-177 / 88, \mathrm{R}-177 / 88$, EUECJ R-177/88.

${ }^{112}$ Bhatt, supra note 28 at 7.
} 
same opportunities as their male counterparts. Thus, in the UK, the Courts set an analogy between pregnancy and sickness. ${ }^{113}$ D.W Austin has shown that from 1990 to 2013, fifty-nine nations have enacted legislation banning bias in job-based sexual consideration. In the last couple of decades, many Supreme Court rulings. For example, Nepal and Pakistan went against discrimination based on sex. ${ }^{114}$

The Constitutions of Portugal, Bolivia, New Zealand, and Ecuador also have equal protection and non-discrimination clause based on sexual orientation. ${ }^{115}$ The Human Rights Act of New Zealand makes it illegal to grant an employee less pleasant circumstances at job placement or other advantages and benefits based on gender discrimination. ${ }^{116}$ On the other hand, the Constitution of Ecuador forbids discrepancy in recognizing, enjoying, or exercising rights based on gender sexual orientation. It further asserts that work is a duty and right of citizens. ${ }^{117}$

\section{J. The Obligatory International Legal Instruments}

The principle of equality is the beginning point of all freedoms. It is one of the most critical human rights, as recognized by almost all international human rights instruments. ${ }^{118}$ As per the international human rights standard, Malaysia is not a human rights-friendly nation because of unsatisfactory human rights scenarios. Non-ratification of maximum international human rights instruments, overwhelming authoritative control, and over-enthusiastic execution of the law by enforcing bodies are chief among all the reasons. Malaysia has endorsed only the convention on the Rights of the Child (CRC), Convention on the Elimination of All Forms of

113 Ibid at 8 .

${ }^{114}$ David Austin et al., "Sexual Orientation and Gender Identity" (2010) Int Lawyer at 547-561.

115 Amy Raub, et al., "Protections of Equal Rights across Sexual Orientation and Gender Identity: An Analysis of 193 National Constitutions" (2017) 28:1 Yale J Law Fem. at 149.

${ }^{116}$ Human Rights Act, 1993, Act 82 (New Zealand), Sec. 21 and 23.

${ }^{117}$ Raub et al, supra note 117 at 158.

${ }_{118}$ Mashood A Baderin, International Human Rights and Islamic Law (OUP Oxford, 2003) at 58. 
Discrimination Against Women (CEDAW), and Convention on the Rights of Persons with Disabilities (CRPD) to date there are at least nine international instruments, which Malaysia yet to approve and rectify. ${ }^{119}$ The Federal Court of Malaysia could favor the appellant in Beatrice Fernandez v Sistem Penerbangan Malaysia E Anor case for the sake of abolishing gender discrimination and establishing equality among the citizens. Even Malaysia was bound to implement at least the terms of the CEDAW that pledges to secure all kinds of civil, political, social, and cultural rights for women. Malaysia has been a part of that instrument since $1995 .^{120}$

\section{CONCLUSION}

Constitutional guarantees are those intrinsic and inalienable rights without which humankind cannot live in the universe as a human being. Therefore, every human being entitles to have these rights by born. None of them is the by-product of any legislation or parliament. Hence, no authority can take them away. Moreover, one of the noble causes of adopting constitutions is to protect the rights of the citizens, not to curtail them. Besides, the bygone political ideology that constitutions are made for protecting citizens from the state's tyranny is only considered the backdated thought. Thus, by offering a wide array of logic ranging from the theological to the religious, sociohistorical study of law to international law theory, constitutional guarantees, especially the equal protection of the law, should apply to both public and private sectors.

There are numerous provisions in the constitution and other existing laws supporting the equal protection of the law. Besides, in this day of liberalism, one should broaden his or her horizon of thinking from the narrow view that constitutional guarantees merely apply against the state agencies. One can choose whom to pick as a cook, or driver, or maid, or to select an academic institution. Likewise, any corporation can instruct on maintaining a formal

\footnotetext{
${ }^{119}$ Rahmat Mohamad, "Ratifying International Conventions," Star Online, online: $<$ https://www.thestar.com.my/opinion/letters/2018/07/30/ratifying-internationalconventions $>$.

${ }^{120}$ Ahmad, supra note 30 at $1-2$.
} 
dress code. Nevertheless, in a large-scale supply chain, public service, public administration, or private corporation, constitutional and administrative law safeguards must apply. The logical interpretation of the constitution, reasonable expectations of law, the normative ideology behind the adoption of the constitution also support this horizontal application of constitutional guarantees.

\section{ACKNOWLEDGMENTS}

None.

\section{COMPETING INTERESTS}

The author declared that he has no competing interests.

\section{REFERENCES}

Abdul Malek Ahmad PCA, et al., "Beatrice Fernandez v Sistem Penerbangan Malaysia \& Anor” (2005) 3:681 Malay Law J.

Ahmad, Salbiah, Gender Equality under Article 8: Human Rights, Islam and 'Feminisms' (Malaysia: The Malaysian Bar, 2005).

Amar, et al., "Child Abuse as Slavery: A Thirteenth Amendment Response to DeShaney" (1992) 105:6 Harv Law Rev.

Anantaraman, Venkatraman, Malaysian Industrial Relations: Law \& Practice (Universiti Putra Malaysia Press, 1997).

Austin, David, et al., "Sexual Orientation and Gender Identity" (2010) Int Lawyer.

Aziz, ZA, Developing the Doctrine of Equality-Sameness and Differences (Malaysia: The Malaysian Bar, 2005).

Baderin, Mashood A, International Human Rights and Islamic Law (OUP Oxford, 2003). 
Barak, Aharon, "Constitutional Human Rights and Private Law" (1996) 3:2 Rev Const Stud.

Barnes, Robert, "Supreme Court Blocks Massive Sex-Discrimination Suit against Wal-Mart," Wash Post, online: <https://www.washingtonpost. com/politics/supreme-court-blocks-massive-sex-discrimination-suitagainst-wal-mart/2011/06/20/AGCQ81cH_story.html>.

Bhatt, Jashpal Kaur, "Gender Discrimination in Employment- how far does Art 8 of the Federal Constitution Guarantee Gender Equality" (2006) 6 Malay Law J.

Cane, P, Public Law and Private Law: A Study of the Analysis and Use of a Legal Concept: Oxford Essays in Jurisprudence, 3 (Oxford: Clarendon Press, 1987).

Clapham, Andrew, Human Rights in the Private Sphere (Oxford: Clarendon Press, 1993).

Coker, Francis William, Readings in Political Philosophy (Macmillan, 1914).

Dalrymple, G Brent, The age of the Earth (Stanford University Press, 1994).

Dhamo, Ana, "United States of America and Constitutional Guarantees" (2015) 6:3 Mediterr J Soc Sci.

Dwivedi, Krishna Chandra, Right to Equality and the Supreme Court (Deep \& Deep Publications, 1990).

Engle, Eric, "Third Party Effect of Fundamental Rights (Drittwirkung)" (2009) 5:2 Hanse Law Rev.

Epstein, Richard A, "In Defense of the Contract at Will" (1984) 51:947 Univ Chic Law Rev.

Erlina \& Nika Normadilla, "Gender Analysis in Indonesia's Legislation Regarding Political Laws” (2020) 7:3 Lentera Hukum.

Faruqi, Shad Saleem, "The Constitution and the Private Sector", Star Online, online: <https://www.thestar.com.my/opinion/columnists/ reflecting-on-the-law/2017/10/26/the-constitution-and-the-privatesector-the-view-that-the-protection-of-the-constitution-is-restrict $>$. 
Fisch, William B, "Emergency in the Constitutional Law of the United States" (1990) 38:Suppl_1 Am J Comp Law 389-420.

Fletcher, George P, "In God's Image: The Religious Imperative of Equality Under Law" (1999) 99 Columbia Law Rev.

Gabriele Ullrich, Hubertus Essenberg \& William Ratterree, The Impact of Decentralization and Privatization on Municipal Services: Report for Discussion at the Joint Meeting on the Impact of Decentralization and Privatization on Municipal Services, by Gabriele Ullrich, Hubertus Essenberg \& William Ratterree, Sectoral Activities Programme (Geneva: International Labour Organization, 2001).

Ghurye, G S, Caste and Race in India (Popular Prakashan, 1969).

Ginsburg, Tom \& James Melton, Innovation in Constitutional Rights (2012).

Graber, Christoph B \& Geunther Teubner, "Art and Money: Constitutional Rights in the Private Sphere?” (1998) 18:1 Oxf J Leg Stud.

Greenhouse, Steven, "A New Hurdle for Suits Brought on Behalf of Many," N Y Times, online: <http://www.nytimes.com/2011/06/21/business/ 21class.html?>.

Harlow, Carol, "Public' and 'Private' Law: Definition without Distinction" (1980) 43:3 Mod Law Rev.

Hart-Davis, Adam, History: From the Dawn of Civilization to the Present Day (Penguin, 2012).

Hasnas, John, "Equal Opportunity, Affirmative Action, and the AntiDiscrimination Principle: The Philosophical Basis for the Legal Prohibition of Discrimination" (2002) 71 Fordham Law Rev.

Hershkoff, Helen, "Positive Rights and State Constitutions: The Limits of Federal Rationality Review” (1999) 112:6 Harv Law Rev.

Hossain, Kamrul, "In Search of Equality: Marriage related Laws for Muslim Women in Bangladesh” (2003) 5:1 J Int Women's Stud.

Jayus, Jayus \& Muhammad Bahrul Ulum, "Presidential Power's Limitation to Emergency Provisions in Indonesia" (2020) 8:2 J Cita Huk 343-362. 
Jennings, I, The Law and the Constitution (London: University of London Press, 1963).

J Mark, Joshua, "The Ancient City," online: World Hist Encycl <https://www. worldhistory.org/city/>.

Kaspersen, L Bo, "Anthony Giddens: The Consequences of Modernity" (1991) 23:1 Politica.

Kitroeff, Natalie \& Jessica Silver-Greenberg, "Pregnancy Discrimination Is Rampant Inside America's Biggest Companies," N Y Times, online: $<$ https://www.nytimes.com/interactive/2018/06/15/business/ pregnancy-discrimination.html>.

Kurniawan, Joeni, "When Human Rights are not Enough" (2018) 2:1 J Southeast Asian Hum Rights 236-247.

Lapidus, Lenora M, Emily J Martin \& Namita Luthra, The Rights of Women: The Authoritative ACLU Guide to Women's Rights (New York: NYU Press, 2009).

Lillich, Richard B, The Human Rights of Aliens in Contemporary International Law (Manchester University Press, 1984).

Lillibridge, Nicole, "The Promise of Equality: A Comparative Analysis of the Constitutional Guarantees of Equality in India and the United States" (2004) 13 William Mary Bill Rights J.

Liu, Goodwin, Pamela S Karlan \& Christopher H Schroeder, Keeping Faith with the Constitution (Oxford University Press, 2010).

Luhmann, Niklas, The Differentiation of Society (Columbia University Press, 1982).

Mears, Bill, "Supreme Court Rules for Wal-Mart in Massive Job Discrimination Lawsuit," CNN, online: <http://edition.cnn.com/2011/ US/06/20/scotus.wal.mart.discrimination/index.html>.

Mitchell, Jonathan F, "Textualism and the Fourteenth Amendment" (2017) 69:5 Stanford Law Rev. 
Mohamad, Rahmat, "Ratifying International Conventions", Star Online, online: <https://www.thestar.com.my/opinion/letters/2018/07/30/ ratifying-international-conventions $>$.

National Women's Law Center, "Supreme Court Decision in Wal-Mart v. Dukes," Natl Womens Law Cent, online: <https://nwlc.org/resources/ supreme-court-decision-wal-mart-v-dukes/ $>$.

Ramachandran, S \& Kessides, "Privatization and Deregulation: A Push Too Far?” in Econ Growth 1990 (World Bank, 1990).

Randhawa, Sharanpal Singh, "Muslim-only Launderette in Perlis", Star Online (29 September 2017), online: <https://www.thestar.com.my/ news/nation/2017/09/29/muslimonly-launderette-in-perlis-ownerwho-does-not-want-controversy-urges-nonmuslims-to-goelsewher/>.

Raub, Amy, et al., "Protections of Equal Rights across Sexual Orientation and Gender Identity: An Analysis of 193 National Constitutions" (2017) 28:1 Yale J Law Fem.

Raz, Joseph, The Morality of Freedom (Clarendon Press, 1986).

Robbers, Gerhard, Encyclopedia of world constitutions (New York: Facts On File, 2007).

Sankaran, Kamala \& Roopa Madhav, Working Paper No.17: Gender Equality and Social Dialogue in India, by Kamala Sankaran \& Roopa Madhav (ILO, 2010).

Tikamdas, Ramdas, "National Security and Constitutional Rights" (2003) 32:1 J Malays Bar 18.

The Financial Express, "A Gender Bending Judgement," Financ Express, online: <https://www.financialexpress.com/archive/a-gender-bendingjudgement/88692>.

Thomas, D, God, Locke, and Equality: Christian Foundations of John Locke's Political Thought (Cambridge University Press, 2001).

Tribe, Laurence H, American Constitutional Law (Foundation Press, 1978). 
210 | Arguments to Apply Constitutional Guarantees in the Private Sector

Willke, Helmut, Stand und Kritik der neueren Grundrechtstheorie: Schritte ze normativen Systemtheorie (Duncker und Humblot, 1975). 